3 Denny-Brown DE. The changing pattern of neurological medicine. $N$ Engl f Med $1952 ; 246: 839-46$.

4 Joynt RJ. The mechanism of production of papilloedema in the GuillainBarré syndrome. Neurology (Minneap) 1958;8:8-12.

5 Morley JB, Reynolds EH. Papilloedema and the Landry-Guillain-Barre syndrome. Case reports and a review. Brain 1966;89:205-22.

(Accepted 29 September 1980)

University Department of Neurology, Institute of Neurological

Sciences, Southern General Hospital, Glasgow G51 4TF

ALISON C REID, MRCP, FRACP, registrar in neurology

I T DRAPER, MB, FRCP, consultant neurologist

\section{Measuring glycosylated haemoglobin concentrations in a diabetic clinic}

The glycosylated haemoglobin $\left(\mathrm{HbA}_{1}\right)$ concentration is a useful index of diabetic control. ${ }^{12}$ Measuring the concentration by chromatography on cation exchange columns, however, requires a skilled technician and controlled temperatures, and the result is not immediately available. We have therefore evaluated a new method (Corning Medical Ltd, Halstead, Essex) that offered accuracy, simplicity, and speed. We assessed the method in our diabetic clinic over six weeks by $(a)$ comparing it with a chromatographic method run concurrently, $(b)$ examining the feasibility of obtaining a result in time for the patient's consultation, and $(c)$ estimating the value of the result.

\section{Patients, methods, and results}

On arrival all patients have their urine tested, are weighed, have their eyesight tested (yearly), and give a finger-prick blood sample for glucose and $\mathrm{HbA}_{1}$ estimations. Often an hour or more passes after arrival before the patient sees the doctor. Some patients arrive well before the clinic starts to minimise this time, and finger-prick sampling was begun on these before $1 \mathrm{pm}$, so that the first results were available by $2 \mathrm{pm}$. Also by seeing mainly new patients first, who need more doctor-time, we hoped to achieve a good flow.

Blood obtained by finger-prick $(10 \mu \mathrm{l})$ was haemolysed in $30 \mu \mathrm{l} 0.1 \%$ saponin, $0.05 \%$ EDTA. Aliquots of haemolysate $(1 \mu \mathrm{l})$ were analysed by electrophoresis and endosmosis on agar gels for 40 minutes and the percentage of $\mathrm{HbA}_{1}$ determined by scanning densitometry. Standard deviation for replicate samples was $0.5 \%$. Details of our chromatographic method have been published. ${ }^{3}$ The value of the measurements was assessed by questionnaire. After seeing each patient the doctor looked at the $\mathrm{HbA}_{1}$ result, decided what advice to give the patient, and then answered four questions: Does this alter your management ? Was the result as expected ? Do you think it usefully reinforced the advice you have given? Did it alter the timing of further follow-up ? Questionnaires were collected at the end of each clinic. Equipment fitted on a standard trolley, and it was found convenient to run the system in the clinic, reagents being non-toxic. The technician took about 30 minutes to learn the method.

The results were closely similar to those of chromatography (figure). In week 1 about half the results were available in time for the consultation. Week 2 was less satisfactory, but by week 3 and thereafter most results were obtained in time. A total of 259 questionnaires were answered. Haemoglobinopathy was identified in 10 cases, which we excluded from analysis. As a result of the measurements patient management was changed in $17 \%$ of cases (ranges $10-25 \%$ over the six weeks and $11-26 \%$ for the six doctors). The result was unexpected in $26 \%$ of cases (ranges $20-33 \%$ and $18-36 \%$ respectively) and was thought usefully to reinforce the advice given in $45 \%$ (ranges $38-56 \%$ and $14-75 \%$ ) and to alter timing of follow-up in $12 \%$ (ranges $5-23 \%$ and $2-23 \%$ ). When the first, third, and fourth questions were combined a positive answer was obtained in $135(54 \%)$ cases.

\section{Comment}

Measuring $\mathrm{HbA}_{1}$ by electrophoresis/endosmosis was simple, accurate, and rapid compared with column chromatography, and most results were obtained during clinic time. Nevertheless, there was some extension of waiting time and overcrowding in our just adequate waiting area, and longer term some adjustments will be necessary. Patients may need to be re-educated into considering a clinic visit as an opportunity for advice partly based on preliminary checks (including $\mathrm{HbA}_{1}$ ) rather than a visit to the doctor preceded by a long wait.

As a result of measuring $\mathrm{HbA}_{1}$ almost one-fifth of patients had their

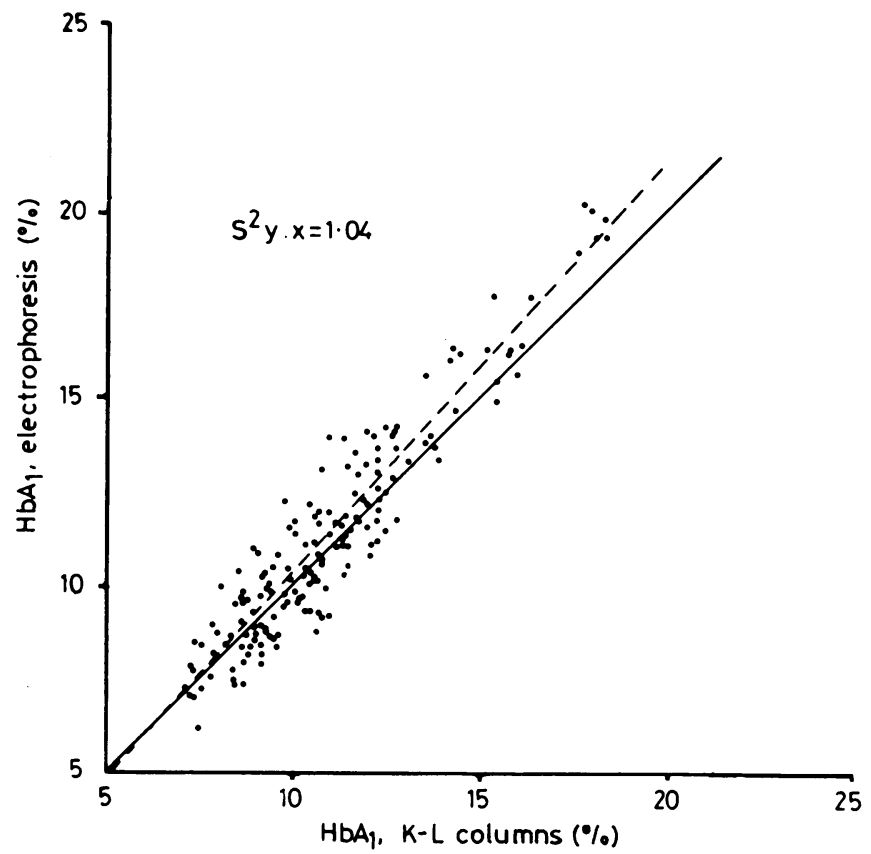

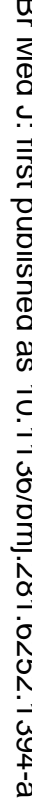

Relation between $\mathrm{HbA}_{1}$ concentrations measured by electrophoresis/ endosmosis and our own modified Kynoch-Lehmann (K-L) columns ${ }^{3}$ $(\mathrm{n}=192) . \mathrm{HbA}_{1}$ by electrophoresis $=1.10 \times \mathrm{HbA}_{1}$ by $\mathrm{K}-\mathrm{L}-0.64$ (- Line of identity. - - - Regression line).

management changed, which is substantially more than after many tests. In over half the measurement was thought to be useful. Further studies will identify patients in whom $\mathrm{HbA}_{1}$ measurement is most valuable.

1 Gonen B, Rubenstein AH. Haemoglobin $\mathrm{A}_{1}$ and diabetes mellitus. Diabetologia 1978;15:1-8.

${ }^{2}$ Dunn PH, Cole RA, Soeldner JS, et al. Temporal relationship of glycosylated haemoglobin concentrations to glucose control in diabetics. Diabetologia 1979;17:213-20.

3 Baron MD, Shenouda FS, Sönksen PH. Micro-column method for $\mathrm{HbA}_{1}$ determination. Lancet 1980 ; :114-6.

(Accepted 8 October 1980)

Department of Medicine, St Thomas's Hospital Medical School, London SE1 7EH

JOHN SAUNDERS, MD, MRCP, lecturer

M D BARON, BA, research assistant

F S SHENOUDA, MB, research assistant

P H SÖNKSEN, MD, FRCP, professor of endocrinology

\section{Spontaneous biochemical remission in parathyroid carcinoma}

Spontaneous remission is an unusual but recognised feature of primary hyperparathyroidism associated with adenoma, and is then attributed to infarction of, or haemorrhage into, the affected gland. A remission seems not to have been described in parathyroid carcinoma. We describe the case of a patient with parathyroid carcinoma who had a spontaneous but temporary biochemical remission which may have been related to tumour infarction.

\section{Case report}

The patient, a man aged 60 , was well until June 1976, when he developed pain in the lower lumbar region. $\mathrm{He}$ also noticed ankle swelling and had lost $7 \mathrm{lb}(3.18 \mathrm{~kg})$ in weight. There was no significant medical history. He was found to have hypercalcaemia and was referred to the metabolic unit, Manchester Royal Infirmary, for further investigation. Clinical examination gave normal findings apart from congenital finger clubbing. Serum concentrations were: calcium $3.75 \mathrm{mmol} / 1(15 \mathrm{mg} / 100 \mathrm{ml})$, inorganic phosphate 
$0.96 \mathrm{mmol} / 1(2.9 \mathrm{mg} / 100 \mathrm{ml})$, alkaline phosphatase $150 \mathrm{IU} / 1$, and urea $3.8 \mathrm{mmol} / 1(23 \mathrm{mg} / 100 \mathrm{ml})$. Serum immunoassayable parathyroid hormone (iPTH) concentration was $13.1 \mu \mathrm{g} / 1$ (normal $0.8 \mu \mathrm{g} / \mathrm{l}$ ). Skeletal radiographs showed subperiosteal erosions of the phalanges and a "rugger-jersey" spine. These findings indicated primary hyperparathyroidism. In March 1977 his neck was explored. A large, encapsulated, tan-coloured tumour $(2.5 \mathrm{~cm} \times$ $2 \mathrm{~cm} \times 2 \mathrm{~cm}$ ) was found in the left lower position. Three other normal-sized nodes were thought to be recognised clinically, but biopsies were not done. The tumour was composed of chief cells and, although the cells had a regular appearance, occasional mitoses were seen, suggesting the possibility of parathyroid carcinoma. He made an uneventful recovery, and the serum calcium and iPTH concentrations returned to normal.

He remained well until June 1978, when he again developed backache. The serum calcium concentration was now raised $(3.8 \mathrm{mmol} / \mathrm{l})$, as was the serum iPTH $(5 \cdot 4 \mu \mathrm{g} / \mathrm{l})$. He was readmitted. The hypercalcaemia was confirmed but while an inpatient his serum calcium concentration fell spontaneously to normal. This change was accompanied by decreases in the serum iPTH and in the urinary nephrogenic cyclic $\mathrm{AMP}^{1}$ and by an increase in the renal tubular reabsorption of phosphate (figure). This remission persisted for
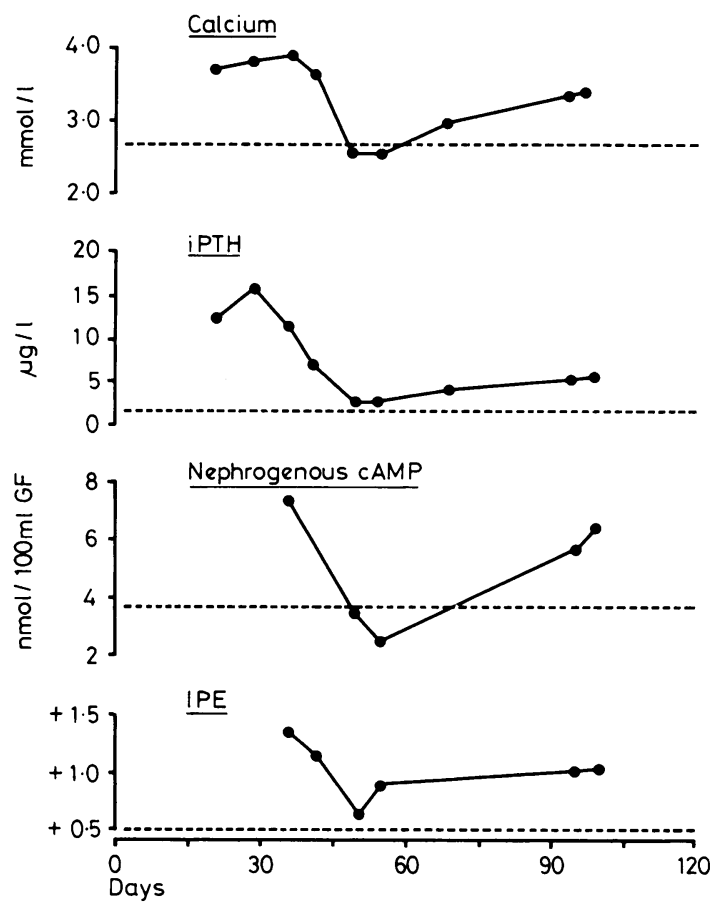

Serum concentrations in case of spontaneous biochemical remission in parathyroid carcinoma (- - - ) shows upper limit of normal range.

Conversion: SI to traditional units-Calcium: $1 \mathrm{mmol} / 1 \approx$ $4 \mathrm{mg} / 100 \mathrm{ml}$.

three weeks. In September 1978, after the return of hypercalcaemia, his neck was again explored and also the mediastinum. A biopsy specimen of tissue taken from the left upper and right lower poles of the thyroid gland showed parathyroid tissue surrounded by adipose tissue and separated by dense fibrous bands. The histology of tissue from sites in the thymic region showed further nests of parathyroid tissue insinuated between thymic lobules. There was a clump of parathyroid cells in a vein. In one of the nests of parathyroid tissue there was an area of granulation tissue containing haemosiderin pigment. The appearances were those of parathyroid carcinoma with possible tumour infarction.

He made a good postoperative recovery and the serum calcium and iPTH concentrations fell to normal. In March 1980 hypercalcaemia recurred (serum calcium $3.15 \mathrm{mmol} / \mathrm{l}$, serum iPTH $1.3 \mu \mathrm{g} / \mathrm{l}$ ) and has persisted.

\section{Comment}

The clinical, operative, and histological findings confirmed that this patient had a parathyroid carcinoma. Spontaneous relapse of hyperparathyroidism was to be expected. In primary hyperparathyroidism associated with adenoma the serum calcium concentration occasionally fluctuates ${ }^{2}$ and may return to normal. Much less common is spontaneous infarction of the affected gland, which may cause a prolonged biochemical remission and sometimes profound hypocalcaemia. ${ }^{34}$ The granulation tissue and haemosiderin pigment found in one of the nests of parathyroid cells suggests localised infarction of the tumour. This might explain the temporary biochemical remission. Hypomagnesaemia, which impairs parathyroid hormone secretion, was not present at any stage. ${ }^{\mathrm{j}}$
This work was supported in part by a programme grant from the Medical Research Council to Professor S W Stanbury. We thank Dr G A Lumb for the PTH assay and Professor P H Adams and Dr M Davies for permission to publish and for helpful advice and criticism.

${ }^{1}$ Broadus AE, Mahaffey JE, Bartter FC, Neer NM. Nephrogenous cyclic adenosine monophosphate as a parathyroid function test. $\mathcal{f}$ Clin Invest 1977;60:771-83.

${ }^{2}$ Willis MR. Normocalcaemic primary hyperparathyroidism. Lancet 1971; i:849-52.

${ }^{3}$ Johnston CC, Schnute RB. A case of primary hyperparathyroidism with spontaneous remission following infarction of the adenoma with the development of hypocalcaemic tetany. F Clin Endocrinol Metab 1961; 21:196-200.

${ }^{4}$ Howard JE, Follis RH, Yendt ER, Connor TB. Hyperparathyroidism. Case report illustrating spontaneous remission due to necrosis of adenomas and a study of the incidence of necroses in parathyroid adenomas. 7 Clin Endocrinol Metab 1953;13:997-1008.

${ }^{5}$ Rude RK, Oldham SB, Sharp CF, Singer FR. Parathyroid hormone secretion in magnesium deficiency. $\mathcal{F}$ Clin Endocrinol Metab 1978;47: 800-6.

(Accepted 24 September 1980)

Division of Metabolism, Department of Medicine, and Department of Pathology, Royal Infirmary, Manchester

P S KLIMIUK, MRCP, lecturer

A R MAINWARING, FRCPATH, consultant histopathologist

\section{Risks from cannulae used to maintain intravenous access}

Over five million intravenous plastic cannulae are used each year in Britain. Most are the Teflon Venflon type with a valved side injection port permitting convenient intermittent intravenous access. This design, however, reportedly increases the possibility of infection, ${ }^{1}$ though evidence is lacking. We have therefore studied prospectively the risks of using the Venflon cannula for intermittent vascular access.

\section{Materials, methods, and results}

During January to March 1980 we studied 102 consecutive Venflon cannulae inserted for at least 24 hours for intermittent or emergency intravenous access in patients in two medical wards. Each entry site was examined for local inflammation (defined as the presence of two or more of noticeable tenderness, redness, swelling, and phlebitis), a skin swab taken, and the site sprayed with $0.5 \%$ chlorhexidine in spirit. The cannula was then carefully removed, the intravenous portion cut off aseptically into a dry sterile container, and a blood specimen taken for culture. The cannula tip was cultured both quantitatively by a roll-plate technique ${ }^{2}$ and qualitatively in nutrient broth. Fifteen cannulae produced definite bacterial growth ${ }^{2}$ on rollplate culture, and these and an additional eight were positive on broth culture.

Cannula infection was significantly associated with positive skin-swab cultures (see table), the same micro-organism (mainly Staphylococcus epidermidis) always being isolated from both sites. Phage typing, biotyping, and antibiograms suggested that out of 12 paired isolates from positive cannula and skin cultures, seven were identical. One patient had Staph aureus grown from all specimens, including blood, and died of septicaemia and acute endocarditis. Cannula infection was not associated with local inflammation or duration of cannulation, though the second two were significantly related (table). Type of medication given through the side port

Relation between cannula infection, skin infection, local inflammation at site of cannulation, and duration of cannulation

\begin{tabular}{|c|c|c|c|c|}
\hline & \multirow{2}{*}{$\begin{array}{l}\text { No of cases } \\
\text { (total }=102)\end{array}$} & \multirow{2}{*}{$\begin{array}{c}\text { No of } \\
\text { positive skin } \\
\text { cultures }\end{array}$} & \multicolumn{2}{|c|}{$\begin{array}{l}\text { Duration of } \\
\text { cannulation (hours) }\end{array}$} \\
\hline & & & Mean $\pm S D$ & Range \\
\hline $\begin{array}{l}\text { Cannulae with positive } \\
\text { roll-plate culture }\end{array}$ & 15 & $13 *$ & $92 \pm 59$ & $24-243 \dagger$ \\
\hline $\begin{array}{l}\text { Cannulae with negative } \\
\text { roll-plate culture } \\
\text { Local inflammation present } \\
\text { Local inflammation absent }\end{array}$ & $\begin{array}{l}87 \\
35 \\
67\end{array}$ & $\begin{array}{l}17^{*} \\
12+ \\
18 \dagger\end{array}$ & $\begin{array}{r}83 \pm 53 \\
112 \pm 63 \\
68 \pm 40\end{array}$ & $\begin{array}{l}24-312 \dagger \\
39-312 \ddagger \\
24-243 \ddagger\end{array}$ \\
\hline
\end{tabular}

* Significant difference $\left(p<0.005 ; \chi^{2}\right.$ test $)$.

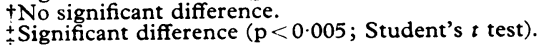

